\title{
When governments write contracts: Policy and expertise in sovereign debt markets
}

\author{
W. Mark C. Weidemaier, Mitu Gulati, and Anna Gelpern*
}

At least three times in the past two decades, national governments and institutions at the regional and international levels have tried to reform sovereign bond contracts to facilitate debt restructuring. Years and continents apart, official actors did not merely regulate private contracts - mandate terms or define acceptable contracting parameters but actively intruded in the drafting process. In most cases, governments that would not legislate or regulate instead nudged, managed, and modeled contract drafting. They convened experts, commissioned reports, and raced to produce model clauses that could be marketed to debtors and creditors. They even tried "to lead by example," using model clauses in some of their own debt contracts. This mode of government intervention, which blurs the role of regulator and market participant, was not invented in the 1990s. The Committee for the Study of International Loan Contracts, which convened under the auspices of the League of Nations in late 1935, used similar methods to promote sovereign debt contract terms, including close cousins of the clauses at the forefront of present-day debates.

Our chapter considers this method of government intervention using majority modification clauses as a case study. ${ }^{1}$ Majority modification is a species of what are now

\footnotetext{
* Weidemaier is faculty at the University of North Carolina School of Law. Gulati is faculty at Duke Law School. Gelpern is faculty at Georgetown Law and a non-resident senior fellow at the Peterson Institute for International Economics. A version of this paper appears in CONTRACTUAL KNOWLEDGE: ONE HUNDRED YEARS OF EXPERIMENTATION IN GLOBAL MARKETS (forthcoming, Cambridge Univ. Press).

1 Portions of this chapter are adapted from Weidemaier and Gulati (2013).
} 
called "collective action clauses" (CACs) in sovereign debt contracts. CAC is an umbrella term for clauses that promote creditor coordination. Majority modification CACs enable some creditors to vote to change the debt obligation and bind the remaining creditors to the outcome. These CACs were prominent in the work of official contract drafters in the 1930s, 1990s, 2000s, and have made two more comebacks since 2010. Indeed, CACs - defined in the broad sense as clauses designed to remedy bondholder coordination problems - have been around for nearly a century.

For decades, bonds issued under English law have allowed for supermajority modification; in many of these bonds, quorum rules reduced the threshold for modification to less than twenty per cent of outstanding debt. Until 2003, however, these clauses were largely confined to the English-law market. In particular, drafting custom in the New York market seemed to preclude majority modification; all known sovereign bonds issued under New York law required each creditor's consent to change payment terms. But beginning with a bond issue by Mexico in February 2003, new sovereign bond contracts under New York law shifted to supermajority modification. The modification provision was revised again in 2014, this time both in the English-law and New York-law markets. At the time we write this, the revision appears to be taking hold rapidly across both markets.

Market-wide contract change of this sort is exceptionally rare. A large literature is devoted to the problem of no change - or boilerplate stickiness - even when the contract term in question is clearly suboptimal (Kahan and Klausner 1997; Gulati and Scott 2013). Modification terms in sovereign bond contracts appeared to be an important case study. The dramatic ascendance of CACs in 2003 was a rare example in which contract drafters overcame their typical inertia. To the public officials who promoted this change, the New York market offered a lesson in market failure. Lawyers and other market participants failed 
to understand the importance of CACs; the official sector could play a key role as catalyst and educator. Subsequent accounts of the shift embraced this narrative (Galvis and Saad 2004; Taylor 2007; Quarles 2010), which later was employed to justify additional waves of contract reform.

A review of sovereign debt contracts, however, reveals flaws in this story. For at least a century, sovereign bonds have demonstrated frequent innovation, including the adoption of new clauses designed to facilitate coordination among bondholders. These innovations did not necessarily result in majority modification clauses of the sort promoted by government officials, but this was not because market participants were unaware of these clauses. The efforts of the League of Nations Committee for the Study of International Loan Contracts (the League Committee) reveal an equally long pedigree for official intervention in sovereign debt contracts. Then, as now, attempts to facilitate the modification of sovereign debt contracts have rested on particular ideas about market failure and ways to overcome it. Then, as now, officials called on market and academic experts from different countries, and turned bond contracts into a technocratic reform project.

In this chapter, we explore the century-long effort to promote majority modification clauses in sovereign bonds, which raises a more fundamental question about the nature of government intervention in the sovereign debt markets. Part I focuses on the interwar years. We explore the League Committee's efforts to promote majority modification clauses, juxtaposing these efforts against contracting practices during the period. We show that parties frequently experimented with ways to address creditor coordination problems, but virtually never adopted majority modification clauses. Part II turns to more recent reform efforts. We present the common story about how majority modification clauses appeared in bonds governed by English but not New York law, and about how the official sector 
catalyzed the 2003 shift in New York. Part III highlights flaws in this story, revealing, once again, a surprising degree of innovation in sovereign debt contracts. We conclude by exploring the implications of our findings.

\section{The interwar period: CACs and the reform agenda}

In the modern era, reform efforts have focused on improving sovereign debt contracts, and majority modification clauses have emerged as a key policy tool. Contemporary narratives justify the need for official intervention by positing that market participants do not fully understand the value of these clauses. But when we look to the preWorld War II era, a different story emerges. Sovereign bonds have selectively employed majority modification clauses for nearly a century. Government-sponsored contract reform efforts have likewise considered the merits of these clauses. Indeed, the League Committee's work in the 1930s bears a striking similarity to contract reform efforts in the 1990s and 2000s. The primary difference is that, in the interwar period, other forms of CAC enjoyed more widespread acceptance.

Modification clauses entered widespread use in English-law bonds in the 1980s, but they have a much longer history. ${ }^{2}$ The earliest example we have found is a 1922 Czech bond issue negotiated in consultation with the League of Nations (see Florès, in this volume). ${ }^{3}$

This was a significant issuance that involved major underwriting banks acting in consultation with governments in creditor countries (Decorzant and Flores 2012). The bonds provided that, at a meeting to consider "any proposal which may be made to them by the

\footnotetext{
2 Our discussion in this section draws on a data set built with the help of a number of academic colleagues. It includes approximately 2,700 sovereign bond contracts and disclosure documents drawn from a variety of sources and covering the period 1823-2012. For a fuller description of the portions of the data set relevant to this chapter, see Weidemaier and Gulati (2013:63-64).

3 The League assisted in arranging reconstruction loans for a number of countries and cities that would otherwise have been unable to access global capital markets. These included Austria, Bulgaria, Estonia, Greece, Hungary, and the city of Danzig. For history on the League Loans, see Myers (1945); Decorzant and Flores (2012). The Czech loans were not among the League Loans but the Czech government requested that any disputes with the banks be arbitrated by the League of Nations (Decorzant and Flores 2012:20).
} 
Czechoslovak Government ..., the decision of the holders of the majority in nominal value of Bonds present at such meeting, either in person or represented by proxy, shall be binding upon all Bondholders..."4 The clause does not limit the range of permissible topics at the meeting and plainly seems to allow a binding vote on a restructuring proposal. A similar clause featuring a two-thirds modification threshold appears in restructured Belgian debt issued in 1936. However, in our data set of 460 pre-World War II bonds, no other bonds allow for majority modification. Indeed, we do not even find this clause in subsequent Czech or Belgian bond issues.

Although majority modification clauses were rare, they were not unknown to official reformers. As the Great Depression unfolded, the idea of looking into debt contracts was apparently driven by the French delegation inside the League Committee. Much as their US and UK successors many decades later, the French did not have the political space to push the process at the time, and asked the Dutch to step in to ensure a proper mandate for the League Committee. Some Committee members had misgivings about the reasons and the need for government intervention. Again and again, Committee staff presented the problem as one of market ignorance, with education by the official sector as the solution. Sovereign debt instruments, including League-sponsored loans, were running into trouble and could not be modified owing to a deadlock among bondholder representatives, or the absence of a legal relationship between creditors and their purported representatives. From the staff perspective, an obvious response was to take care of the representation problem up front, in the debt contracts.

\footnotetext{
${ }^{4}$ Bond for Czechoslovak State Loan of 1922; Listing Application for the Czechoslovak State $\$ 14,000,000$ Eight Percent. Bonds (January 11, 1923); Listing Application for the Czechoslovak State \$9,250,000 Eight Percent. Bonds (February 3, 1925).
} 
During the interwar era, standing committees played a much larger role in negotiating a settlement following default (Eichengreen and Portes 1989; Eichengreen 1991). The Corporation of Foreign Bondholders played the dominant role in negotiating on behalf of British bondholders and, in the 1930s especially, the Foreign Bondholders Protective Council played a key role in negotiating on behalf of US bondholders. ${ }^{5}$ Their negotiated settlements, however, did not bind dissenting bondholders, and this concerned League Committee staff. Modification clauses offered one solution.

Staff informed the Committee about prevailing market practices. A background memorandum prepared for the Committee in 1937 identified the modification clauses in the Czech and Belgian bonds but conceded that, "[i]n international loan contracts, majority clauses have so far been rare" (League Committee 1937). Although staff members had a generally receptive attitude toward majority modification, this perspective ran up against Committee members' skepticism about intruding into private contract drafting, and especially "the aversion ... now felt by the Committee to contracts containing clauses as to their revision." 6

League finance officials responded to Committee skepticism by lining up experts with historical and comparative studies to show that the reforms they proposed channeled accepted practices the world over, and should be entirely uncontroversial. This approach was particularly striking with respect to majority modification:

The purpose of the document is to show that the possibility of modifying loan contracts by meetings of bondholders authorized to do so in the loan contracts is a well known practice in Great Britain, based on a long tradition. Documents giving details on similar situations in other countries (Canada, U.S.A., and a number of Continental countries) have already been circulated to the Committee ... As you may be aware, the Committee has, at its first meeting, refused point blank to envisage or discuss the possibility of

\footnotetext{
${ }^{5}$ On the complex relationship between the State Department and the FBPC, see Adamson (2002).

${ }^{6}$ Memorandum from De Bordes to Lovejoy, October 1, 1937.
} 
modifying contracts, and the preparation of these documents is in the nature of a flank attack to make it take up this exceedingly important question again. If we can show that bondholders in a number of countries are used to and have accepted the principle, it will be more difficult to resist it as regards international loans. ${ }^{7}$

This was a case of considerable "spin." For example, Committee briefings describe US practice as favoring majority modification, though a careful reader would notice that modifying payment terms required unanimous consent.

Despite initial reluctance among the members, the Committee's final report included several options for ensuring a debt settlement "binding on all bondholders" (League Committee 1937). These options did not, however, include majority modification clauses. In fact, the Committee's report primarily focused on non-binding methods of improving bondholder coordination, such as trustees and bondholder representatives. In this respect, the Committee's report mirrored market practice. In our data set, approximately 5 percent of pre-World War II bonds included collective acceleration clauses, and nearly 24 percent provided for a trustee to represent bondholder interests (Weidemaier and Gulati 2013).

Despite official concern, the idea that effective debt adjustment requires the participation of all bondholders did not seem to take hold until much later. Perhaps the most notable example of this indifference involves the 1922 Czech bonds, which contained the very first modification clause. Given the economic and political upheaval of the ensuing decades, these bonds not surprisingly went into default. After World War II, the Czech government entered into wide-ranging restructuring negotiations, including with the Council of Foreign Bondholders and the Foreign Bondholders Protective Council (FBPC). The FBPC archives at Stanford University include drafts of the restructuring agreements and related correspondence. Notwithstanding the modification clause in the underlying bonds -

${ }^{7}$ Letter from De Bordes to McKinnon Wood, September 24, 1937. 
which, recall, allowed bondholders holding a majority in nominal value of the debt, voting at a meeting or by proxy, to approve "any proposal which may be made to them by the Czechoslovak Government" in a vote "binding upon all Bondholders" - we found no indication in the archives that any of the negotiating parties ever considered calling such a meeting or otherwise attempted to bind dissenters. Every draft of the restructuring proposal envisioned that individual bondholders could assent to the plan by tendering their bonds to be stamped with notice of the restructuring. ${ }^{8}$

It is tempting to attribute this indifference to binding holdouts to the fact that sovereigns enjoyed absolute immunity from suit during the interwar period. Yet by the 1930s, officials already saw lawsuits as a problem. According to the League Committee, "Too many lawsuits would be a bad thing; not only would they be unpleasant for the debtors, but their Stock Exchange effects would be disastrous in the case of international loans (double quotations, speculation, arousing of false hopes or misgivings among the bondholders)" (League Committee 1937:33). To limit the threat of lawsuits, however, the League Committee turned not to majority modification but to a narrower remedy: a bondholder vote to initiate litigation. One implication of this decision in the modern context is that, even if litigation can pose a barrier to sovereign restructurings, majority modification clauses are not the only potential solution. And in fact, until the sovereign debt crises of the 1980s and 1990s, majority modification clauses were almost never discussed seriously as an important mechanism of financial market reform.

\section{Modern contract reform and the "discovery" of CACs}

Although the sovereign bond markets were vibrant throughout much of the nineteenth and early twentieth centuries, the Depression brought bond lending to an abrupt

\footnotetext{
${ }^{8}$ See, for example, Terms for resumption of service proposed by Czechoslovak Govt., Czechoslovak State Loan of 1922 (First Series and Series B) (1946).
} 
halt. Countries continued to issue bonds sporadically and in small amounts, but the market did not revive in earnest until the 1990s (Flandreau et al. 2009; Flandreau, Gaillard, and Panizza 2010). Contemporary narratives date the "discovery" of CACs as a policy tool to the crises that followed soon after. CACs, of course, were not new. But as CACs assumed greater policy significance, the fact that many bond contracts did not use them called out for an explanation. In the sections that follow, we explore the contract reform efforts that began in the 1990s and continue today, and we highlight flaws in how reformers accounted for the (relative) lack of CACs in the marketplace. What remains is a picture with striking parallels to the 1930s: governments working to change prevailing contract terms, acting on the stated assumption that the market was not working properly.

\section{The road to CACs (the 1990s and 2000s)}

The modern history of sovereign debt contract reform begins in the aftermath of Mexico's “Tequila Crisis" of 1994-1995. Political turmoil, capital flight, and a plummeting currency put pressure on Mexican bonds, especially the short-term dollar-indexed tesobonos. If Mexico could not refinance or repay them, there seemed to be no way to restructure them. The specter of a messy default brought back fears of another Third World Debt crisis and "lost decade," a repeat of the 1980s. US finance officials, working with counterparts in other wealthy countries and multilateral institutions, engineered a rescue package. Creditor governments cited the difficulty of bond restructuring as a justification for the politically unpopular "bailout." The logical next step was to make bond restructuring plausible. The official postmortem was prepared by a "working party" under the auspices of the Group of Ten (G-10), a gathering of finance officials dominated by representatives of central banks. It proposed two options - treaty-based bankruptcy and a set of contract clauses to promote 
coordination, including creditor representation, majority modification, and sharing clauses. The statutory option was rejected outright; CACs remained.

The report, euphemistically entitled "The Resolution of Sovereign Liquidity Crises," (Group of Ten 1996) was noteworthy for several reasons. It was prepared by a G-10 group chaired by a Belgian official, Jean-Jacques Rey (hence its name, the "Rey Report") apparently chosen as a compromise between the United States, thought to favor bailouts, and Germany, thought to be hyper-averse (Gelpern and Gulati 2006). The compromise message was that to the extent crises were expected to recur, official resources to resolve them were limited. Bond restructuring was a possibility, and bondholder coordination would prove useful in that event. Bankruptcy, however, was both unnecessary and unattainable. Contract clauses would be helpful, but would not be mandated.

This was a muted warning and a cautious set of recommendations. Even so, the contract reform line was puzzling, since it targeted New York-law bonds in response to a crisis in tesobonos, which were Mexican-law instruments. To our knowledge, no one had bothered to investigate whether these bonds could be restructured by contract, statute, or fiat. It might have been reasonable for officials to speculate that a foreign-law bond crisis was just around the corner, or simply to use the discussion of well-understood New Yorklaw contracts as a platform to signal a broad policy change. But these justifications were not expressly stated.

In any case, advocacy of CACs was not a cheap rhetorical throwaway. It relied on academic research and market soundings to determine market practice and the extent to which officials would be willing to push it (Eichengreen and Portes 1995; Kenen 1996; Group of Ten 1996). The working party recommended three sets of contract clauses, one of which was majority modification. By this time, majority modification clauses had become 
commonplace in London, and appeared patently unobjectionable, especially since many emerging markets investors held both New York and English law bonds. But why was the New York market so behind the curve in adopting it? The Rey Report pointed to simple ignorance, a product of market segmentation:

The resistance to qualified majority voting clauses expressed by market participants in some countries may be attributed to a lack of familiarity with such clauses in their national context. Increased public awareness of the extent to which qualified majority voting clauses are already used in some bonds, and official support for efforts by the private sector to make greater use of such clauses, should, over time, allow market participants to become more familiar and comfortable with the clauses both in principle and in practice (Group of Ten 1996:20-21).

And so officials set out to increase public awareness and market comfort with CACs. These efforts had barely begun when the Asian Financial Crisis struck, occasioning another round of soul-searching. Again, foreign-law bonds did not figure in the crisis, but were prominently featured in the policy response document issued by the Group of Twenty Two (G-22) wealthy and developing countries, represented by senior officials from finance ministries and central banks. The recommendation essentially carried over from the Rey Report:

To encourage the adoption of such "collective action clauses," the Working Group recommends that their governments give consideration to: (i) engaging in educational efforts with identified constituencies in major financial centres to promote the use of collective action clauses in sovereign and quasisovereign bonds issued in foreign offerings; (ii) identifying sovereign and quasi sovereign issuers likely to come to their markets soon and encouraging such issuers to use the collective action clauses; and (iii) examining the use of such clauses in their own sovereign and quasi sovereign bonds issued in foreign offerings (Group of Twenty Two 1998).

Again, education and outreach were front and center, though officials now considered both direct prodding of likely issuers and "leading by example" by including CACs in their own 
bonds. ${ }^{9}$ Speeches and exhortations continued for a while, but as far as the official sector knew, the market would not budge.

CACs largely receded from public view as the crisis waned. They came back with a vengeance under a new US administration, which felt pushed into bailing out Argentina in the run-up to its 2001 default. The story of how CACs re-emerged as a policy tool is wellknown and involves a contest between contract reform and a treaty-based restructuring mechanism supported by the IMF (Gelpern and Gulati 2006). Leery of “top-down" institutional solutions, US officials gravitated to contract change as a substitute. They dusted off CACs, though a slightly different set than had been proposed in the Rey Report. Majority modification, however, remained a centerpiece of the US-supported policy recommendations.

As part of an intensifying education campaign, CAC advocates at the US Treasury yet again called on the G-10, this time to produce model clauses that could be adopted by sovereign issuers. The group was chaired by Randal Quarles, a partner at the law firm of Davis Polk before his government appointment. The Quarles group commissioned draft clauses from leading law practitioners, which were issued together with the policy recommendations. This drafting effort was accompanied by relentless outreach, where Taylor and his deputies would call and cajole individual finance ministers and underwriters to use majority modification in their next bond issue. G-10 drafters also found themselves in

\footnotetext{
${ }^{9}$ This was a meaningful statement inasmuch as the group included both wealthy and developing countries. On the one hand, it is not clear to what extent the developing country members of the group were expected to follow through. On the other hand, the idea of wealthy countries leading by example was either naive or disingenuous. Emerging markets finance officials repeatedly said in interviews that they viewed rich country contract practices as largely irrelevant to their own. They worried about the pricing effects of CACs, and expected them to diverge for the two groups of countries. Moreover, since most wealthy countries issued the bulk of their debt under their own laws, the commitment to adopt CACs in foreign-law bonds was essentially an empty promise for many members of the group, notably the United States.
} 
competition with private industry groups that had finally decided to take official

exhortations to heart and produce their own model CACs (Group of Ten 2002).

The decisive shift in sovereign debt contracts came, courtesy Mexico, which included majority modification in a 2003 issue of New York-law bonds (Haseler 2009). Part of the story is that Mexico's status as a market leader was crucial to the shift in New York-law bonds. ${ }^{10}$ After Mexico, Brazil, and Uruguay issued New York bonds with CACs, the market turned on a dime. Focusing only on collective modification clauses, Figure 1 illustrates the shift. Before 2003, only a handful of New York-law bonds included collective modification clauses. After 2003, these clauses appeared in nearly every issuance (Weidemaier and Gulati 2013; Bradley and Gulati 2014).

Figure 1. Collective modification clauses in bonds governed by New York law.

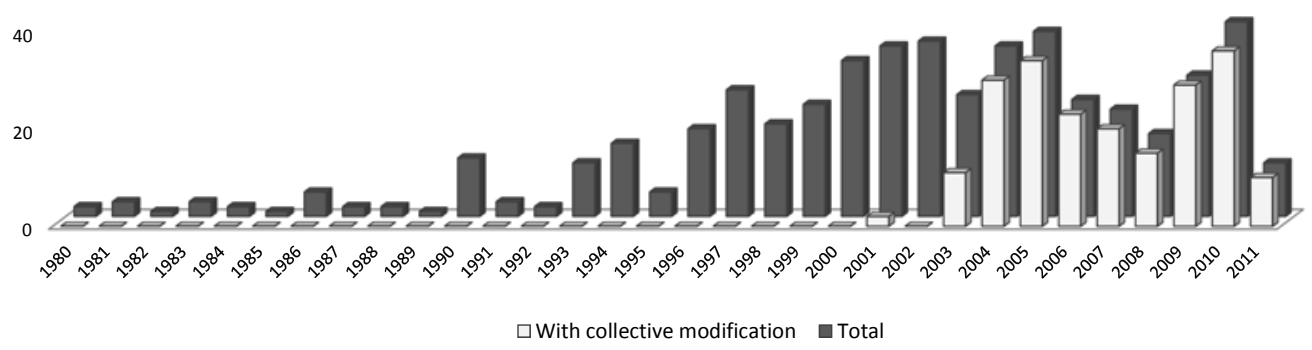

Officials declared victory, and with good reason: the shift was unprecedented in the history of contract boilerplate, and could not have happened without them by all accounts. Education and outreach worked; markets saw the light and improved their contracts. CACs again receded from public view.

\footnotetext{
10 This was because many market participants worried that CACs would raise their borrowing costs. The fear had some grounding in theory: if CACs reduce the need for bailouts and facilitate "private sector involvement" in debt restructuring, private lenders might price this risk into their loans. On the other hand, CACs might also reduce the cost associated with protracted restructuring negotiations, and this might lower borrowing costs. Without a test case, it was not clear that any country would risk adding CACs to their bonds. Moreover, the test case could not be a small country on the market periphery. No one would follow the lead of such a bit player. Only a market leader could prompt a widespread change in contracts. The first mover and negative signal stories are discussed in Haseler (2009) and Eichengreen (1991).
} 


\section{Some flaws in the narrative - episodic use of CACs}

This broader narrative of official intervention overcoming market ignorance was always somewhat at odds with the facts. For one thing, most English-law bonds already had modification clauses (Bradley and Gulati 2014). Additionally, although most New York-law bonds required unanimity, researchers discovered a handful of bonds from the 1980s and 1990s with modification clauses. The ubiquity of modification clauses in the English-law market, and their occasional appearance in New York, raised the possibility that the choice of unanimity was a deliberate one. ${ }^{11}$ For example, sovereign issuers in New York tended to have lower credit ratings (Bradley and Gulati 2014). Investors in the New York-law market might have worried more about restructuring and wanted to exercise more control in that event (Weidemaier and Gulati 2013). To be sure, investors who expect to restructure might value majority modification as a tool for making the inevitable go more smoothly. Then again, they might turn to terms and techniques other than majority modification to accomplish the task (Bi, Chamon, and Zettelmeyer 2012). In sum, if market participants were aware of majority modification CACs, they might have rejected them in New York for any number of perfectly rational reasons. If this was a case of deliberate rejection, official promotion of majority modification is harder to justify.

CAC advocates adapted their narrative of market failure to accommodate these market practices. The account that emerged again emphasized lawyer ignorance. As the story goes, sovereign lending in the 1970 s primarily took the form of syndicated commercial loans. Lawyers responsible for documenting sovereign bond issues in the 1980s and 1990s allegedly based the new sovereign bond documents on the closest template they could find:

\footnotetext{
${ }^{11}$ In theory, the unanimity requirement could have served multiple functions. For example, some investors may have preferred bonds that made restructuring harder, and these buyers may have dominated the New York-law market (Weidemaier and Gulati 2013).
} 
cross-border corporate bonds (Weidemaier and Gulati 2013). In the United States, the Trust Indenture Act of 1939 forbids the use of majority modification clauses in corporate bonds. The architects of this prohibition viewed bankruptcy as the preferred alternative (Roe 1987). For sovereigns, however, bankruptcy is not an option. Had lawyers been more attentive to the need to provide for a coordinated workout process, they would have modified corporate bonds to make them suitable for sovereign borrowers. But their inexperience with bond lending meant lawyers did little more than copy the corporate template.

This story ruled out investor preference as an explanation for the absence of majority modification clauses in the New York sovereign market. It also offered a basis for explaining the prevalence of majority modification in English-law bonds. The lawyers there, the story goes, simply copied English-law corporate bonds (or sovereign bonds derived from that template). Because of legal differences between the markets, the English law corporate template included CACs (Buchheit and Gulati 2002). ${ }^{12}$

The inadvertent copying story also provided an explanation for the occasional use of majority modification in New York. Two researchers at the Reserve Bank of Australia, Mark Gugiatti and Anthony Richards (2004:815), discovered most of the early New York CACs. The issuers were relatively obscure ones - Kazakhstan, Lebanon, Bulgaria, Egypt, and Qatar - and had been using majority modification clauses in their New York law bonds since the late 1990s. Another instance of pre-Mexico CACs was in the World Bank-guaranteed bond issued by the state-owned Thai power company (Liu 2004).

Gugiatti and Richards (2004:823) attributed pre-Mexico CACs in New York-law bonds to accident. They posited that the lawyers who drafted these New York-law bonds

\footnotetext{
12 The copying story drew further support from the fact that English-law CACs might, in theory, allow a restructuring to proceed with the support of only a minority of bondholders (Weidemaier and Gulati 2013). To many observers, this made them seem ill suited for the sovereign context (Group of Ten 2002).
} 
inadvertently began with English-law forms. According to the story, the lawyers who drafted the bonds worked in the London offices of New York firms, and they simply began with the (wrong) forms that were familiar to them. Gugiatti and Richards (2004:826) raised the question "whether the lawyers involved were cognizant of the innovative nature of the legal terms being used." Their answer, delicately phrased, was no: "[O]ur assessment is that [with one exception] the inclusion of CACs was not necessarily a deliberate decision and was perhaps even somewhat inadvertent" (Gugiatti and Richards 2004:827). For reformers, the story had clear implications, which Gugiatti and Richards (2004:827) spelled out: “[T]he marketplace has historically paid little or no attention to this particular aspect of bond contracts... [T] he inclusion of CACs has simply not been an important decision variable for borrowers or investors."13

Like the other copying stories, this one also supports the broader narrative of market failure. After all, if the New York-law CACs that preceded Mexico resulted from deliberate choice, this might imply that their omission elsewhere was similarly deliberate. The next section suggests, however, that inadvertent copying stories are hard to square with the contracts themselves.

\section{Indonesia, 1983 and 1986}

All of the bonds uncovered by Gugiatti and Richards (2004) were issued in the late 1990s. ${ }^{14}$ We have uncovered modification clauses in two New York-law issues dating back to the 1980s. These bonds were issued by Indonesia in 1983 and $1986 .^{15}$

\footnotetext{
13 The Thai guaranteed bond was somewhat inconvenient for the story because it had been drafted by the Hong Kong office of a New York firm. The explanation given here was that this bond was somehow sui generis because it involved a co-guarantee from the International Bank for Reconstruction and Development (the World Bank).

14 The earliest issue was in 1997.

15 A caveat: the sales documents for these bonds do not specify the vote required to change payment terms. Instead, they refer readers to the Fiscal Agency Agreement, which we have not located. Theoretically, the Fiscal Agency Agreement could set a voting threshold of 100 percent, but we doubt this is the case. This
} 
The modification clauses found in these Indonesian bonds cannot easily be attributed to blind copying of London forms. The issues were managed out of New York. The law firms involved were White and Case for the issuer, and Sullivan and Cromwell for the underwriters. The roster of legal advisers in the prospectus includes Sullivan and Cromwell's New York office and three White and Case offices (New York, London, and Hong Kong). In theory, the bond template could have originated from White and Case offices in London or Hong Kong. However, because the underwriter's counsel typically provides the basic contract template (Gulati and Scott 2013, Chapter 2), it is more likely that the form originated in Sullivan and Cromwell's New York office. This is especially so in the Indonesian sovereign offering, because Sullivan and Cromwell was much more active in the sovereign market than White and Case at the time (Bradley et al. 2014).

Lawyers at Sullivan and Cromwell knew how to draft New York-law bonds and had plenty of forms at their disposal. It seems implausible that they would have copied the template from London, unless the issuer or the underwriter specifically requested the English law contract form or particular provisions, such as majority modification.

\section{Lebanon, 1997}

The earliest New York-law bond contracts with CACs identified by Gugiatti and Richards (2004:823) documented a 1997 bond issue by Lebanon, backed by a World Bank guarantee. ${ }^{16}$ The US lawyers who led the work on this issue were based in New York, not London. Dewey Ballantine, headquartered in New York, represented the underwriters; Freshfields, headquartered in London, represented the issuer. Assuming standard practice,

would be an odd way to disclose that the bond's payment terms could not be modified. Moreover, it is typical for English-law bonds to refer to the underlying agency agreement for information about voting thresholds for modification. New York-law bonds typically disclose the unanimity requirement in the prospectus itself.

${ }^{16}$ Citing July 2 Lebanon Offering Circular. 
Dewey Ballantine would have provided the deal template, both because it was counsel for the underwriters and because the issuance was to be governed by New York law.

Yet even if these New York-law bonds began with English-law forms, the evidence suggests that the lawyers involved were engaged in design, not copying. Within months of its first issuance in 1997, Lebanon issued a second bond governed by New York law. Once again, Dewey Ballantine was counsel for the underwriters. This time, however, the lawyers involved worked at Dewey Ballantine’s London office. ${ }^{17}$ They could have used Lebanon's English-law templates, from a bond issued only two years earlier, in 1995. They did not. Below, we reproduce the modification clause in Lebanon's 1995 English-law bonds and the modification clause in its 1997 New York-law bonds. The emphasis is ours and reveals important differences.

\section{Lebanon, July 25, 1995; \$300 million; 9.125 percent bonds due 2000 (English Law)}

The Agency Agreement contains provisions for convening meetings of the Bondholders to consider matters affecting their interests, including the modification by Extraordinary Resolution of these Conditions or the provisions of the Agency Agreement. The quorum at any meeting for passing an Extraordinary Resolution will be one or more persons present holding or representing a clear majority in principal amount of the bonds for the time being outstanding, or at any adjourned meeting one or more present whatever the principal amount of the Bonds held or represented by him or them, except that at any meeting the business of which includes the modification of certain of these Conditions the necessary quorum for passing an Extraordinary Resolution will be one or more persons present holding or representing no less than two-thirds or at any adjourned meeting not less than one-third, of the principal amount of the Bonds for the time being outstanding. An Extraordinary Resolution passed at any meeting of the Bondholders will be binding on all Bondholders, whether or not they are present at the meeting, and on all Couponholders.

\section{Lebanon, October 29, 1997; \$400 million; 8.625 percent bonds due 2007 (New York Law)}

The Fiscal Agency Agreement contains provisions for convening meetings of Bondholders to consider any matter affecting their interests, including the modification of these Conditions or the provisions of the Fiscal Agency Agreement, provided that no modification of the Conditions or the Fiscal Agency Agreement may be had

\footnotetext{
17 The issuer's counsel was once again Freshfields.
} 
without the consent or affirmative vote (by person or proxy) of persons holding or representing no less than 75 percent in aggregate principal amount of Bonds then represented at the relevant meeting of Bondholders which would (i) change the due date for any amount payable by the Republic under the Bonds; (ii) reduce or cancel any portion of the principal amount of Bonds or the amount of interest or any other amount payable under the Bonds or modify the rate of interest on the Bonds; (iii) modify the currency of payment under the Bonds; (iv) change the identity of any Person obligated under the Bonds or the release, in whole or in part, of any such Person; or (v) modify the provisions of the Conditions or the Fiscal Agency Agreement relating to the quorum required at any meeting of Bondholders or the percentage of Bondholders required to pass any resolution or otherwise modify the provisions summarized in this paragraph. A resolution duly passed in accordance with the provisions of the Fiscal Agency Agreement at any meeting of the Bondholders will be binding on all Bondholders whether or not they are present at the meeting and whether or not they vote in favor.

At a minimum, the lawyers in Lebanon's second issuance of 1997 were choosing between two models of majority modification. The 1995 clause resembles the standard English-law modification clause of the period (Bradley and Gulati 2014). It specifies diminishing quorum requirements where, at an adjourned meeting, a small minority of bondholders could potentially modify the bond's payment terms. By contrast, the New York-law bond issued in October 1997 conditions modification on a vote of holders of 75 percent of the aggregate principal amount of the debt. The elevated voting threshold makes sense in the context of Rey Report consultations (conducted just a year earlier), which suggested that US investors viewed English modification requirements as too lax (Group of Ten 1996). In response to an inquiry about their motives from one of the authors, Lebanon's lawyers explained that they had deliberately sought to create a "hybrid" clause that "anticipat[ed] the need to restructure sovereign debt" without leaving open the possibility that a minority of bondholders could approve a restructuring (as in English-law bonds). ${ }^{18}$

\footnotetext{
${ }^{18}$ Letter from Louise Roman Bernstein at Dewey \& LeBoeuf to Mitu Gulati (July 17, 2008) (on file with authors).
} 


\section{Thailand, 1998}

In October 1998 the Kingdom of Thailand guaranteed a New York-law bond issued by its state-owned electricity generating authority. ${ }^{19}$ The country was still suffering from the worst financial crisis in modern memory; its firms had lost access to the global capital markets. Meanwhile, multilateral institutions were looking for ways to stretch their resources to respond to the Asian crisis. As a result, this Thai parastatal bond issue got a nonaccelerable principal guarantee and a single rolling coupon guarantee from the World Bank (1999). ${ }^{20}$ Many in the official sector knew about this bond owing to the novel guarantee structure.

The bond contracts contained a modification clause; this fact was also known to the officials promoting CACs at the time, though not before the bonds were issued. The Thai offering coincided with the release of the G-22 recommendations on CACs in sovereign and quasi-sovereign bonds in October 1998. ${ }^{21}$ The law firms involved included the Singapore and Thailand offices of White and Case, the Hong Kong office of Cleary Gottlieb, and the Thailand office of Freshfields. There was no obvious reason why that issue documentation should have been a product of blind copying from London models, though some speculated that the World Bank guarantee made standard drafting templates inapplicable in this case. Perhaps where the creditors' surest source of repayment - the World Bank - could not be accelerated in the event of default, it behooved everyone involved to consider interim restructuring scenarios with unusual care, which led them to CACs. In sum, the Thai issue was innovative in many respects; CACs were one of them; but in all, it was sui generis.

\footnotetext{
19 See Electricity Generating Company of Thailand, $\$ 300$ million bond, issued October 13, 1998,7 percent bond due 2008 .

20 Because the present value of a long-term, non-accelerable guarantee is very low, and a single coupon is small, the budget cost of the guarantee to the World Bank was very small at the outset.

${ }^{21}$ Report of the Working Group on International Financial Crises.
} 
Our data set, however, includes one other government-guaranteed bond that includes a modification clause, and this one is not accompanied by a multilateral guarantee. Issued less than a month after the Thai experiment, this was a New York law bond guaranteed by the Czech Republic and issued by its domestic airline, Aero Vodochody. ${ }^{22}$ Once again, White and Case was involved, representing the underwriters out of its Prague office. ${ }^{23}$ We have no ready explanation for why majority modification clauses appeared in these (but only these) two guaranteed New York-law bonds in 1998; one possibility is experimentation by a particular law firm - though copying from EGAT in Aero is a possible subplot. ${ }^{24}$

We see little evidence that these early New York-law modification clauses can be attributed to blind copying. The more plausible explanation seems to be that these were small issuers, operating on the margins and under the radar screen, for whom the standard New York-law template did not work. And so they embraced CACs. Whether other players in the New York market could do the same thing without official sector orchestration is another question. What is clear, however, is that official actors were not inclined to let evidence of market experimentation derail the market failure narrative.

\section{Contract reform (re)redux}

The success story crafted by CAC promoters implied that, by the mid-2000s, CACs were everywhere. Consequentially, CACs again receded from public view. But they came

\footnotetext{
22 See Aero Vodochody, \$200 million, issued November 10, 1998, 7.5 percent bond due 2005 .

23 The issuer counsel was the Prague office of the US firm, Altheimer \& Grey.

${ }^{24} \mathrm{We}$ also found modification provisions in issuances by one sub-sovereign in 1999: a bond issued by the Italian city of Florence under New York law. See City of Florence, Offering Circular (April 29, 1999); City of Florence, Pricing Supplement (October 19, 1999). The modification clause in this bond cannot plausibly be attributed to drafter error or copying. The Florentine Offering Circular explicitly specifies both a unanimity provision and a non-unanimity modification provision and states that subsequent pricing supplements should be understood to use the non-unanimity provision unless a particular supplement explicitly adopts the unanimity provision. Ibid. Terms and Conditions at 79-80 (Section 15(a) "Meetings requiring majority consent," and Section 15(b) "Meetings requiring unanimous consent").
} 
back in the unlikeliest of places: Europe. When it turned out in 2010 that Greece was insolvent and would likely need a bond restructuring, CACs quickly emerged as a prominent policy response. This time, there was little effort to articulate a need for them. Finance officials simply invoked the G-10 effort from 2002, without elaborating the collective action problem that might necessitate a similar solution. ${ }^{25}$ Bailouts were a concern, but the notion that CACs would obviate bailouts was even more tenuous this time around. Seven years into the CAC revolution, there was little evidence that the clauses affected the level of official financing in crisis. In Europe - including Greece - most debt was also governed by domestic law, and it could be amended relatively easily by statute. ${ }^{26}$ Much of it was held by regulated financial institutions, notoriously susceptible to moral suasion. There was simply nothing to suggest that the barriers to Greek debt restructuring were legal rather than political or economic. Nevertheless, a standing committee of European debt managers was charged with designing CACs for both domestic and foreign debt of EU member states. Lawyers were hired, experts were polled, and drafting began anew.

The European effort differed from its recent predecessors in several ways. First, CACs were mandated by treaty. Each Eurozone member state committed to adopt CACs by entering into the treaty establishing the European Stability Mechanism (a crisis response vehicle). Standardization was an express goal, since European CACs were supposed to be functionally "identical." And the clauses that emerged were designed, in the words of one lawyer involved, "for countries that did not default." (Gelpern and Gulati 2013) For example, they contained an aggregation feature and far lower voting thresholds than the now-prevalent emerging market CACs, and allowed voting by entities owned or controlled

\footnotetext{
${ }^{25}$ Statement by the Eurogroup (November 28, 2010), www.consilium.europa.eu/press/pressreleases/2010/11/pdf/Statement-by-the-Eurogroup.

${ }^{26}$ This is just what Greece did in 2012 (Zettelmeyer et al. 2013).
} 
by the sovereign debtor. ${ }^{27}$ Greece notwithstanding, Europe stood united in telling bondholders that contracts did not matter.

Ironically, it was Greece that showed the world the limits of the CAC miracle. When it finally restructured its debt in 2012, it enacted a statute to amend over 90 percent of its debt, issued under Greek law, by retrofitting a bondholder voting mechanism dramatically out of line with market practice on CACs. The statute's quorum requirement of 50 percent combined with a voting threshold of $2 / 3$ ensured that a mere $1 / 3$ of its creditor body could bind the rest. Although Greece's foreign-law debt contained "real” CACs - embedded in contracts in line with long-standing practice under English law - more than half of the bondholder votes attempted in this group failed to garner the majority required to amend. Holdouts under these instruments continue to be paid on schedule. Put differently, had Greece's restructuring depended on the CACs that won over the market after 2003, it might well have failed.

At exactly the same time in 2012, litigation stemming from Argentina's 2001 default was demonstrating new risks from holdout lawsuits. A federal court granted holdout creditors the right to block payments on Argentina's restructured debt, raising fresh concerns about creditor participation in future restructurings (IMF 2013). While Greece demonstrated that CACs could not block holdouts, Argentina demonstrated that holdouts were a real threat. Suddenly, the triumph of 2003 and the brand-new European initiative modelled after it looked woefully incomplete. Contract reforms that took so much time, effort, and political capital seemed partial at best, and beside the point at worst. By targeting individual clauses, with no capacity to alter the broader contracting framework, officials seemingly missed the point. Whatever gains they secured in majority modification could be

27 EFC Subcommittee on EU Sovereign Debt Markets, 'Supplemental Explanatory Note' (2012), http://europa.eu/efc/sub_committee/cac/cac_2012/index_en.htm. 
undone in other parts of the contract, or simulated with other restructuring techniques (Panizza et al. 2009; Bi, Chamon and Zettelmeyer 2012).

The officials' response? A new round of contract reform, gaining speed as we write. An informal working group convened by the US Treasury gathered market participants, officials from wealthy and emerging market countries and multilateral institutions, and academics, all with an eye toward promoting the adoption of new contract terms. The consultations resulted in a set of model clauses, published in August of 2014 by the International Capital Market Association (ICMA) (2014) and supported by a nearly contemporaneous report issued by the IMF (2014). The new clauses, modelled on the Greek "retrofit" statute used two years earlier, would permit a majority of creditors to amend their contracts in a single vote across different bond series, binding potential holdouts. Shortly after their initial publication, the ICMA clauses appeared with minor variations in several new bond issues by Mexico, Kazakhstan, and Vietnam. The rapid adoption by both major and small, infrequent issuers raised hopes that the clauses would quickly disseminate through the market. Whether this will spell the end of government-led contract reform, or encourage more, bolder efforts, is a question for another day.

\section{Conclusion}

For much of the life of the sovereign bond markets, officials not party to the bond contracts have tried to change their terms through research, education, and model drafting. This distinct mode of government intervention has focused, to a surprising degree, on the narrow range of contract clauses that fall under the CAC umbrella. Within this subset, official attention has narrowed even further, with modification clauses assuming key policy significance. 
Of course, it is hard to fashion a coherent picture from a century of contracting practices. The snapshots we present in this paper are hardly dispositive. Even one sovereign bond issuance is the product of multiple individuals operating within different institutions having different goals and incentives. We do not pretend to offer a complete explanation of the role CACs have served in the sovereign debt markets. That said, our examination of contracts seems to depart from the standard narrative on the emergence of CACs in New York, which in turn became the predicate for the revival of CACs in the euro area, London, and New York.

First, the interest in reforming sovereign bond contracts in general, and modification clauses in particular, is hardly new. The League Committee tried mightily to improve on market standard in the 1930s. Its experts then did many of the same things that their successors did in the 1990s and 2000s - surveying market practices, searching for the origins of certain terms, and commissioning model clauses for private parties to adopt going forward. Then as now, officials seemed to assume that market participants needed a nudge to innovate. Market actors would benefit from the "spade work" of government officials on their behalf, getting a valuable education in legal and economic history and comparative law, which would catalyze innovation that they could not manage on their own. Perhaps the major difference between government drafting efforts of the 1930s and their contemporary successors is the comprehensive focus of the former. Government drafters in the $1930 \mathrm{~s}$ sought to take a broad view of contract reform, and as a result, came up with a relatively diffuse set of recommendations. Officials in the 1990s and 2000s have maintained a sharp focus on majority modification, even as other clauses have crept on and off the agenda, and 
as innovations in restructuring techniques have made much of the agenda questionable if not obsolete. ${ }^{28}$

On the other hand, even back in the 1930s, there was evidence that private contract drafters were engaged in a fair amount of experimentation, from the rare use of collective acceleration clauses to the more frequent use of trustees (24 percent of our pre-War sample). These clauses, however, never entered widespread use. At all times, officials attributed the scarcity of CACs to market failure rather than to targeted innovation and deliberate choice. To us, this tendency represents a puzzle. Historical evidence tells us that the bond markets have a greater capacity to innovate than reformers attribute to them. Market participants have long been familiar with CACs - defined in the broad sense as clauses that facilitate bondholder coordination - and have frequently adopted, adapted, and improved upon them. So why should governments assign these clauses such policy value? And why majority modification in particular?

Holdouts may pose a greater threat today than at any point in history. Now that lawsuits against sovereigns may do more than create hassle on the margins - indeed, now that holdouts have achieved some rather spectacular (if perhaps temporary) victories ${ }^{29}$ perhaps CACs have become more important as tools to limit holdout litigation. ${ }^{30}$ If so, this does not explain the focus on modification clauses over other contractual methods for addressing holdout concerns. Nor does it link majority modification CACs to the other official-sector justification for them: the imperative to stop bailouts. The link between bailouts and CACs has never been tightly drawn. It is absurd to suggest that recent bailouts

\footnotetext{
${ }^{28} \mathrm{Bi}$ et al., 'The problem that wasn't'.

${ }^{29}$ For example, seizing an Argentinian naval vessel, see Benson (2012), and obtaining an injunction that may require Argentina to choose between paying holdouts or defaulting on its restructured debt, see NML Capital Ltd. v. Republic of Argentina, 699 F3d 246 (2nd Cir. 2012).

30 This assumes the clause is properly drafted (Gelpern 2012).
} 
- of Greece in 2010, or of Mexico in 1995 - had anything to do with the absence of CACs from the relevant bonds (Gelpern and Gulati 2013). Majority modification CACs have become a talisman, invoked to imply that small contractual tokens can ward off the great problems associated with sovereign borrowing in interconnected global markets. ${ }^{31}$

The dominant narrative of the emergence of CACs abets this practice by suggesting that contract reform is beyond the capacity of individual market actors, but can be achieved or at least catalyzed with official involvement deep in the contractual substance. We too share the belief that bond contracts may not contain the optimal set of terms (Gulati and Scott 2013). But a more accurate historical narrative begins by acknowledging that the bond markets exhibit more innovation than is often acknowledged. Perhaps governments can play a salutary role in encouraging widespread use of contract terms; this is not the same as innovating from scratch.

We have not solved the puzzle of official involvement in sovereign bond contract drafting. However, the surprising consistency in official methods gives us pause. When governments refuse to act as regulators, but act instead as market participants, it makes for a useful thought experiment to take them at their word. Perhaps the real problem officials are trying to solve is not one of third-party private contract drafting, but rather a harder problem of governance. Time and again, governments in some countries find themselves as guarantors of other governments' debts. Fear of contagion prods them to pay on the guarantee, despite deep misgivings about fiscal outlays and moral hazard. Private creditors then lend based on the implicit guarantee. Officials find themselves unable to solve the contagion problem, nor the policy problems in other countries that give rise to crises, and

\footnotetext{
31 As noted earlier, CACs appear to be the solution du jour. For example, we have also seen proposals to add collective action clauses to bonds issued by US municipalities. See Remarks of James E. Spiotto, Field Hearing on the State of the Municipal Securities Market (July 29, 2011), www.sec.gov/spotlight/municipalsecurities/statements072911/spiotto.pdf.
} 
this validates private creditors' expectations of a rescue. Officials then try to limit their taxpayers' losses and control moral hazard by "bailing in" private creditors. Because governments put a premium on preserving flexibility in systemic crisis response, they refuse to structure "bail-ins" through regulation. In contrast, contract reform to facilitate bond modification makes it easier for officials to ask private creditors to share in the crisis losses. Against this background, presumptive resistance to contract reform among creditors may not be a surprise after all.

\section{References}

Adamson, Michael R. 2002. "The failure of the foreign bondholders protective council experiment, 1934-1940.” 76 Business History Review 479.

Bi, Ran, Marcos Chamon, and Jeromin Zettelmeyer. 2012. “The problem that wasn't: coordination failures in sovereign debt restructurings.” IMF Working Paper 11/265.

Bradley, Michael and Mitu Gulati. 2014. "Collective action clauses for the eurozone: an empirical analysis.” 18 Review of Finance 2045-2102.

Buchheit, Lee C. and G. Mitu Gulati. 2002. "Sovereign bonds and the collective will." 51 Emory Law Journal 1324-1326.

Decorzant, Yann and Juan H. Flores. 2012. "Public borrowing in harsh times: the league of nations loans revisited," Universidad Carlos III de Madrid Working Papers in Economic History, Working Paper No. 12-07.

Eichengreen, Barry and Richard Portes. 1989. "After the deluge: default, negotiation, and readjustment during the interwar years," in Barry Eichengreen and Peter H. Lindert 
(eds.), The International Debt Crisis in Historical Perspective. Cambridge: MIT Press.

Eichengreen, Barry J. and Richard Portes. 1995. Crisis? What Crisis? Orderly Workouts for Sovereign Debtors. Center for Economic and Policy Research.

Eichengreen, Barry. 1991. "Historical Research on International Lending and Debt." 5 Journal of Economic Perspectives 149-169.

Flandreau, Marc, Juan Flores, Norbert Gaillard, and Sebastián Nieto-Parra. 2009. "The end of gatekeeping: underwriters and the quality of sovereign bond markets 1815-2007." NBER Working Paper No. 15128.

Flandreau, Marc, Norbert Gaillard, and Ugo Panizza. 2010. "Conflicts of interest, reputation, and the interwar debt crisis, banksters or bad luck?” HEID Working Paper.

Galvis, Sergio J. and Angel L. Saad. 2004. "Collective action clauses: recent progress and challenges ahead." 35 Georgetown Journal of International Law 713.

Gelpern, Anna. 2012. Sovereign Restructuring After NML v. Argentina: CACs Don’t Make Pari Passu Go Away, Credit Slips, May 3. www.creditslips.org/creditslips/2012/05/sovereign-restructuring-after-nml-vargentina-cacs-dont-make-pari-passu-go-away.html

Gelpern, Anna and Mitu Gulati. 2006. "Public symbol in private contract: a case study." 84 Washington University Law Review 1656.

Gelpern Anna and Mitu Gulati. 2013. “The wonder clause.” 41 Journal of Comparative Economics 367-385. 
Group of Ten. 1996. "The Resolution of sovereign liquidity crises.” www.bis.org/publ/gten03.pdf

Group of Ten. 2002. "Report of the G-10 Working Group on Contractual Clauses," www.bis.org/publ/gten08.pdfGroup of Twenty Two. 1998. "Report of the Working Group on International Financial Crises.” www.bis.org/publ/othp01d.pdf

Gugiatti, Mark and Anthony Richards. 2004. "The use of collective action clauses in New York law bonds of sovereign issuers." 35 Georgetown Journal of International Law 815.

Gulati, Mitu and Robert E. Scott, 2013. The Three and a Half Minute Transaction: Boilerplate and the Limits of Contract Design. Chicago: University of Chicago Press.

Haseler, Sonke. 2009. "Collective action clauses in international sovereign bond contracts whence the opposition." 23 Journal of Economic Surveys 882.

International Capital Market Association. 2014. Standard Collective Action and Pari Passu Clauses for the Terms and Conditions of Sovereign Notes, ICMA (August 29, 2014), www.icmagroup.org/resources/Sovereign-Debt-Information

International Monetary Fund. 2013. "Global financial stability report: transition challenges to stability.” www.imf.org/External/Pubs/FT/GFSR/2013/02/pdf/text.pdf

International Monetary Fund. 2014. Strengthening the Contractual Framework to Address Collective Action Problems in Sovereign Debt Restructuring, IMF (September 2, 2014), www.imf.org/external/pp/longres.aspx?id $=4911$

Kahan, Marcel and Michael Klausner, 1997. "Standardization and innovation in corporate contracting (or "the economics of boilerplate")." 83 Virginia Law Review 713. 
Kenen, Peter B. (ed.). 1996. From Halifax to Lyons: What Has Been Done About Crisis Management? Princeton: Princeton University International Economics Section.

League Committee. 1937. "Report of the League of Nations Committee for the Study of International Loan Contracts." Legal Questions Concerning International Loans, Note on the Literature of the Subject, Part III, Trustees and Bondholders' Representatives, November 19, 1937.

Liu, Yan. 2004. "Collective Action Clauses in International Sovereign Bonds." IMF Working Paper. https://www.imf.org/external/np/leg/sem/2002/cdmfl/eng/liu.pdf

Panizza, Ugo et al. 2009. “The economics and law of sovereign debt and default.” 47 Journal of Economic Literature 651-98.

Quarles, Randal. 2010. "Herding cats: collective action clauses in sovereign debt - the genesis of the project to change market practices in 2001 through 2003." 73 Law and Contemporary Problems 29.

Roe, Mark J. 1987. “The voting prohibition in bond workouts.” 97 Yale Law Journal 232.

Taylor, John B. 2007. Global Financial Warriors: The Untold Story of International Finance in the Post-9/11 World. New York: W. W. Norton \& Company, Inc.

Weidemaier, W. Mark C., and Mitu Gulati. 2001. “A people’s history of collective action clauses." 54 Virginia Journal of International Law 51.

Weidemaier W. Mark C., and Mitu Gulati. 2013. "How markets work: the lawyer's version.” 62 Studies in Law, Politics, and Society 107. 
World Bank. 1999. Project Finance and Guarantees, 'Thailand: EGAT Paves the Way' http://siteresources.worldbank.org/INTGUARANTEES/Resources/EGATThaila nd PFG Note.pdf

Zettelmeyer, Jeromin et al. 2013. “The Greek debt restructuring: an autopsy.” Economic Policy. 28: 513-563. 